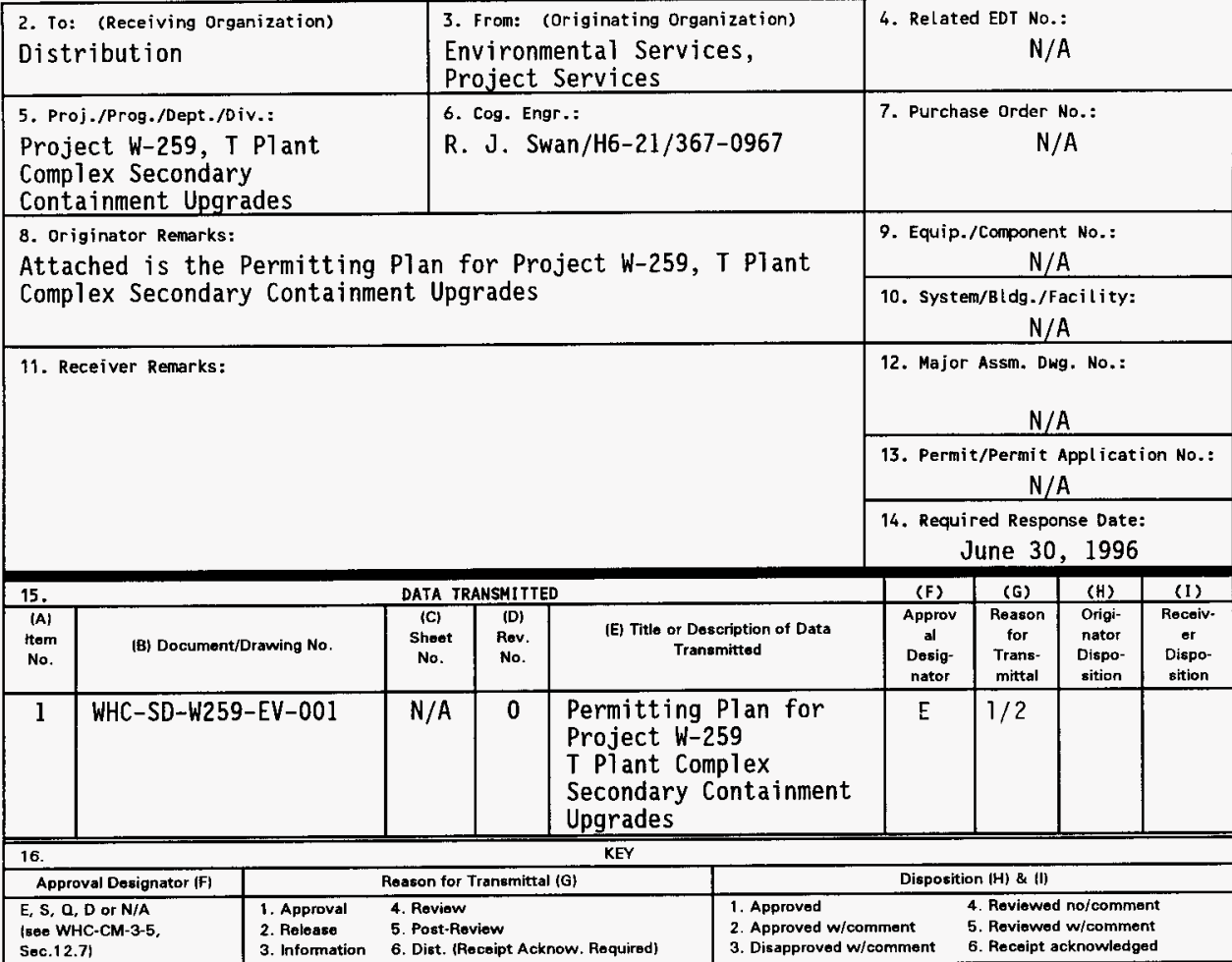

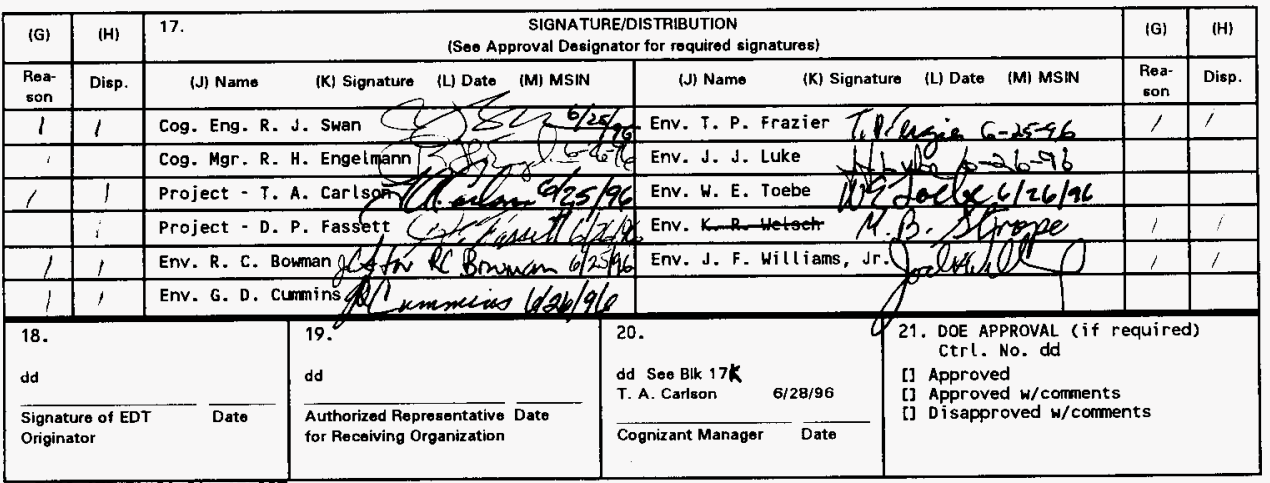




\title{
Permitting Plan for Project W-259, T Plant Complex Secondary Containment Upgrades
}

\author{
R. J. Swan
}

Westinghouse Hanford Company, Richland, WA 99352

U.S. Department of Energy Contract DE-AC06-87RL10930

\author{
EDT/ECN: $615843 \quad$ UC: 2000 \\ Org Code: $01810 \quad$ Charge Code: AB12A \\ B\&R Code: EW3130020 Tota1 Pages: 34
}

Key Words: T Plant, Permitting, Environmental

Abstract: This permitting plan evaluates environmental regulations for Project $W-259$, T Plant Complex Secondary Containment Upgrades.

Described within this document are the environmental reviews, permits and approvals required for the project, as well as the applicable regulatory authority(s). This document also provides the project with a recommended regulatory strategy. including alternatives, in order to successfully secure environmental reviews. permits and approvals in accordance with project objectives.

TRADEMARK DISCLAIMER. Reference herein to any specific commercial product, process, or service by trade name, trademark, manufacturer, or otherwise, does not necessarily constitute or imply its endorsement, recomendation, or favoring by the United States Government or any agency thereof or its contractors or subcontractors.

Printed in the United States of America. To obtain copies of this document, contact: WHC/BCS Document Control Services, P.O. Box 1970, Mailstop H6-08, Richland WA 99352, Phone (509) 372-2420; Fax (509) $376-4989$.
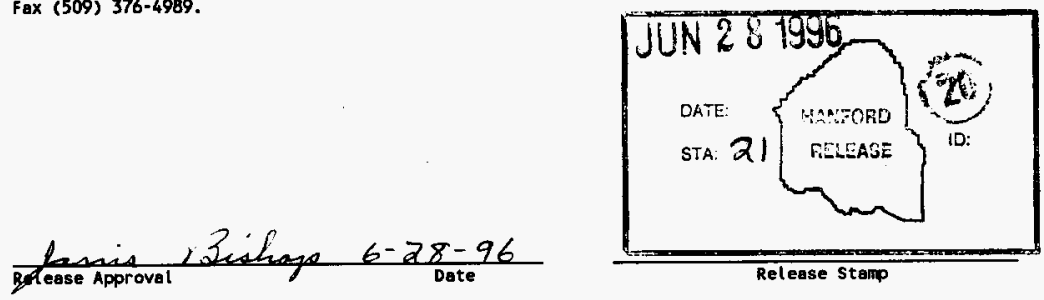
WHC-SD-W259-EV-001, Rev. 0

\author{
PERMITTING PLAN
}

FOR

PROJECT W-259

T PLANT COMPLEX SECONDARY CONTAINMENT UPGRADES

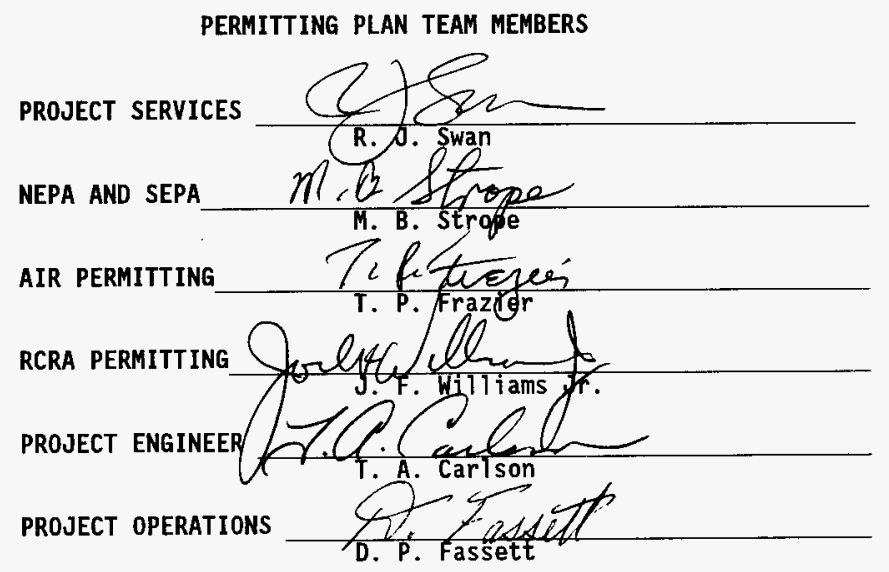


WHC-SD-W259-EV-001, Rev. 0

This page intentionally left blank. 
WHC-SD-W259-EV-001, Rev. 0

\section{EXECUTIVE SUMMARY}

This document describes the permitting plan for Project $W-259$, T Plant Complex Secondary Containment Upgrades. The recommended regulatory strategy is included with a preferred project approach.

A comprehensive review of environmental regulations has indicated that several environmental reviews (e.g. Nationa7 Environmenta7 Po7icy Act of 1969 , State Environmental Policy Act of 1971), permits, and approvals are required before construction or operation of Project $W-259$. The environmental reviews, permits, and approvals, as well the regulatory authority, potentially applicable to the upgrades associated with T Plant Complex Secondary Containment Upgrades Project are as follows:

National Environmenta7 Policy Act of 1969 (NEPA) - U.S. Department of Energy-Richland Operations Office (DOE-RL)

- Categorical Exclusion

- Environmental Assessment

- Environmenta1 Impact Statement.

State Environmental Policy Act of 1971 (SEPA) - Washington State Department of Ecology (Ecology)

- Determination of Nonsignificance

- Mitigated Determination of Nonsignificance

- Determination of Significance

- State Environmenta7 Policy Act of 1971 Environmental Checklist.

\section{Air Permitting}

- National Emission Standards for Hazardous Air Pollutants (40 Code of Federal Regulations 61 Subpart H)

- Prevention of Significant Deterioration standards (40 Code of Federal Regulations 52.21) and (Washington Administrative Code Chapter 173-400)

- Ambient Air Quality Standards for Radionuclides (Washington Administrative Code Chapter 173-480)

- Radiation Protection - Air Emissions (Washington Administrative Code Chapters 246-247)

- Controls for New Sources of Toxic Air Pollutants (Washington Administrative Code Chapter 173-460).

Dangerous Waste Permitting--Dangerous Waste Permit (Washington Administrative Code Chapter 173-303). 
WHC-SD-W259-EV-001, Rev. 0

Miscellaneous Reviews. Permits, and/or Approvals

- Preoperation Monitoring of Facilities, Sites and Operations U.S. Department of Energy, Richland Operations Office

- Cultural Resource Review Clearance - U.S. Department of Energy, Richland 0perations office

- Excavation Permit - U.S. Department of Energy, Richland Operations Office

- Endangered Species Act of 1972 Approval - U.S. Department of Energy, Richl and Operations Office.

A summary of data requirements, alternative strategies for completion of upgrade activities, and approval requirements are presented. 
WHC-SD-W259-EV-001, Rev. 0

CONTENTS

EXECUTIVE SUMMARY ..................... . . . .

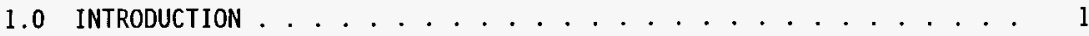

2.0 NATIONAL ENVIRONMENTAL POLICY ACT . . . . . . . . . . . 2

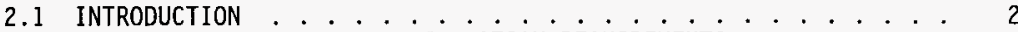

2.2 SUMMARY OF DATA AND/OR INFORMATION REQUIREMENTS ....... 2

2.3 DISCUSSION OF ALTERNATIVES . . . . . . . . . . . 2

2.4 RECOMMENDED NEPA STRATEGY . . . . . . . . . . . . . 3

3.0 STATE ENVIRONMENTAL POLICY ACT . . . . . . . . . . . . . . . 3

3.1 INTRODUCTION . . . . . . . . . . . . . . . 3

3.2 SUMMARY OF DATA AND/OR INFORMATION REQUIREMENTS . . . . . . . . 4

3.3 DISCUSSION OF ALTERNATIVES ............... 4

3.4 RECOMMENDED SEPA STRATEGY . . . . . . . . . . . . . . . 4

4.0 RESOURCE CONSERVATION AND RECOVERY ACT . . . . . . . . . . . . . . 4

4.1 INTRODUCTION ....................... 5

4.1 .1 Notice of Intent . . . . . . . . . . . 5

4.1 .2 Part A.................. . . 5

4.1.3 Part B . . . . . . . . . . . . . . 5

4.2 SUMMARY OF DATA/INFORMATION REQUIREMENTS . . . . . . . . . . . 6

4.3 DISCUSSION OF ALTERNATIVES .................. . . . . 6

4.4 RECOMMENDED PERMITTING STRATEGY . . . . . . . . . . . . . 6

5.0 THE CLEAN AIR ACT . . . . . . . . . . . . . . . . . 6

5.1 INTRODUCTION .................... . . 6

5.1.1 Radioactive Emissions . . . . . . . . . . . . . 7

5.1.2 Nonradioactive Emissions ............ 8

5.2 SUMMARY OF DATA/INFORMATION REQUIREMENTS . . . . . . . . . 8

5.3 DISCUSSION OF ALTERNATIVES . . . . . . . . . . . . . . . 8

5.4 RECOMMENDED PERMITTING STRATEGY . . . . . . . . . . . 9

6.0 MISCELLANEOUS ASSESSMENTS, PERMITS, AND APPROVALS . . . . . . . . 9

6.1 CULTURAL RESOURCE REVIEW . . . . . . . . . . . . . . . . 9

6.2 EXCAVATION PERMIT . . . . . . . . . . . . . . . 10

6.3 ENDANGERED SPECIES ACT COMPLIANCE . $\ldots . . . . . . . .10$

6.4 PREOPERATIONAL MONITORING OF FACILITIES, SITES, AND OPERATIONS .............................. 10

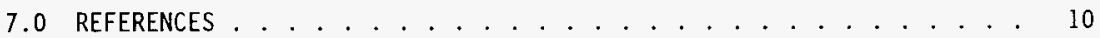


WHC-SD-W259-EV-001, Rev. 0

\section{APPENDICES}

A PROJECT W-259 T-PLANT COMPLEX SECONDARY CONTAINMENT UPGRADES PERMITTING SCHEDULES . . . . . . . . . . . . . . . APP A- $\mathrm{i}$

B SUMMARY OF DATA/INFORMATION REQUIREMENTS FOR PROJECT W-259, T-PLANT COMPLEX SECONDARY CONTAINMENT UPGRADES . . . . . . . APP B- $i$ 


\section{PERMITTING PLAN FOR \\ PROJECT W-259 \\ T PLANT CONPLEX SECONDARY CONTAINMENT UPGRADES}

\subsection{INTRODUCTION}

The T Plant Complex has been selected as the primary interim decontamination location for the Hanford Site. The project plans to upgrade the 2706-T and 2706-TA buildings and erect a new 2706-TB building, to advance that mission. Project $W-259$ supports major decontamination activities identified in the Hanford Federal Facility Agreement and Consent Order, Milestone M-32-03, "Complete T Plant Actions", (Ecology et al. 1996). Construction is scheduled to begin at the end of calendar year 1996.

The primary function of the 2706-T/TA buildings is the decontamination of equipment, tools, and materials that have been contaminated with low-level radioactive and mixed wastes. The role of the 2706-T/TA buildings is now being expanded to include waste treatment and repackaging. The expansion will allow management and handling of miscellaneous items that could be received. Solid waste from decontamination activities will be appropriately disposed of onsite.

Project $W-259$ activities will provide upgrades for secondary containment, leak detection, and decontamination capabilities to comply with environmental and safety regulations. The project will provide additional collection, filtration, transfer, and storage capabilities at T Plant, including upgrades to the automotive and railroad pits. The 2706-T/TA building will decontaminate vehicles and equipment contaminated with low-level radioactive and mixed wastes. A new filtration system and liquid waste load-out system will be added above the railroad pit.

A new 2706-TB building and concrete pad will be constructed adjacent to the existing 2706-T/TA building for management of radioactive and mixed decontaminated waste. Two new stainless steel storage tanks [i.e., 56,781 liters (15,000 gallons) and 22,712 1iters (6,000 gallons)] are to be located within the 2706-TB containment building. Both tanks will be provided with concrete secondary containment catch basins, sized to catch 110 percent of the tank volume. Leak detection systems, transfer piping, and basin and/or pit sump liners will be supplied to the tanks. The ancillary equipment will have secondary containment. A high-efficiency particulate air (HEPA) filtration system will be installed in the vents of the tanks. A waste transfer pipe from the 221-T canyon to the 2706-T/TA building will be connected to the new tanks. Microprocessors for monitoring, alarms, and controlling waste transfer levels to the tanks will be encompassed in the project.

This permitting plan has been prepared based on the "Engineering Evaluation Report for Project $W-259$, T Plant Secondary Containment and Leak Detection Upgrades) (WHC 1995b). 
WHC-SD-W259-EV-001, Rev. 0

\subsection{NATIONAL ENVIRONMENTAL POLICY ACT}

The NEPA (42 USC 4321 et seq.) was enacted to ensure that environmental matters are considered before initiation of federal actions that might affect the quality of the human environment. The U.S. Department of Energy (DOE) regulations [10 Code of Federal Regulations (CFR) 1021] promulgated under NEPA were developed to conform with 40 CFR 1500-1508 regulations and to categorize the environmental impacts associated with various DOE proposals or actions.

\subsection{INTRODUCTION}

If a proposed action appears to be covered under an existing approved environmental impact statement (EIS) or environmental assessment (EA), the relevant record of decision (ROD) or finding of no significant impact (FONSI) should be examined to ensure the proposed action is adequately bounded by existing documentation.

In the event that U.S. Department of Energy, Richland Operations office (DOE-RL) determines that a proposed action is not covered by existing environmental documentation, an evaluation would be required to determine whether the proposed action falls within one of the categorical exclusions (CX) per 10 CFR 1021. If the proposed action is covered by a CX, a memorandum is prepared that summarizes the proposed action and its background. In addition, an explanation of how the action meets the minimum requirements of a CX is needed.

If the proposed action is not covered by a $C X$, a decision whether or not the project warrants an EA or EIS must be made by the DOE-RL.

Following a decision by the DOE-RL, an EA would be developed to discuss the environmental consequences of the proposed action and the alternatives to that action, including the consequences of accidents and routine operations and the cumulative and long-term impacts. The relationship of the proposed action to federal, state, and local land use plans, policies, and regulations also is discussed in the EA. The EAs are submitted to the DOE-RL for final determination. This determination would result in a decision that the proposed action is a major action significantly affecting the environment, requiring an EIS, or issuance of a FONSI.

\subsection{SUMMARY OF DATA AND/OR INFORMATION REQUIREMENTS}

A summary of the minimum data and/or information needs required for development of the NEPA documentation for Project W-259, T Plant Complex Secondary Containment Upgrades is provided in Appendix B.

\subsection{DISCUSSION OF ALTERNATIVES}

The alternatives open for consideration are as follows. The alternative are listed in order of probability of success. 
1. NEPA will be covered by a CX, which was prepared on August 2, 1994 for Project $W-259$.

2. Alternative 2 is the possibility of NEPA coverage under an existing EIS.

\subsection{RECOMMENDED NEPA STRATEGY}

It has been determined that Project $W-259$ is covered under a $C X$ prepared on August 2, 1994. On June 28, 1995, a review of the revised project scope was completed. This 1995 review concluded that the activities were still covered under the original CX [WHC Internal Memo 01880-95-072 (WHC 1995a)]. It was determined that the modifications will be minor and that the original role of the property with decontamination work will not change.

\subsection{STATE ENVIRONMENTAL POLICY ACT}

The SEPA (Chapter 43.21C Revised Code of Washington) legislation is the Washington State equivalent of NEPA, which requires evaluation of environmental impacts associated with a project or an agency action before approval. The SEPA Rules, Washington Administrative Code (WAC) Chapter 197-11, are the implementing regulations.

\subsection{INTRODUCTION}

One regulatory agency will be identified as lead agency for each project. The lead agency is responsible for ensuring that SEPA compliance is completed before approving the proposed project. Compliance with SEPA is required for any project or proposal that meets the definitions of "action" in the SEPA Rules (WAC 197-11-704), and includes projects that require a permit (e.g., dangerous waste permit, building permit) or other approval from a governmental agency before operation. On the Hanford Site, Washington State Department of Ecology (Ecology) is the lead agency for projects ("Actions") involving permitting of dangerous waste treatment, storage, and/or disposal (TSD) units.

The SEPA compliance is required, in addition to other permits or approvals, for a project and is completed before the lead agency makes a decision to approve the project. On the Hanford Site, a SEPA environmental checklist is prepared and submitted to Ecology. The permit and/or approval may be conditioned or denied based on information contained in the SEPA environmental checklist.

When SEPA compliance is required for a project, the responsible official of the lead agency must make a threshold determination by deciding if a project is likely to have probable significant adverse impacts on the environment. If a project might have significant adverse impacts, a determination of significance (DS) will be issued and a state environmental 
impact statement (SEIS) would be required. If the project will not have significant adverse impacts, or if the impacts could be mitigated, a determination of nonsignificance (DNS) or mitigated DNS will be issued. The threshold determination normally is based on the environmental checklist completed for the project and any information the lead agency has on file.

The lead agency may adopt a NEPA EA or EIS in lieu of doing a SEPA checklist or additional review under SEPA (WAC 197-11-610) to satisfy SEPA compliance and a determination of nonsignificance (DNS) or mitigated DNS will be issued.

\subsection{SUMMARY OF DATA AND/OR INFORMATION REQUIREMENTS}

A summary of the minimum data and/or information needs required for development of the SEPA documentation for the Project $W-259$, T Plant Complex Secondary Containment Upgrades is provided in Appendix B.

\subsection{DISCUSSION OF ALTERNATIVES}

The SEPA avenues evaluated in an effort to support Project $W-259$, T Plant Complex Secondary Containment Upgrades are as follows. The alternatives are 1 isted in order of the probability of success.

1. A DNS from Ecology.

2. A mitigated DNS from Ecology.

\subsection{RECOMMENDED SEPA STRATEGY}

It is expected that Ecology will require preparation of a SEPA environmental checklist. The checklist is expected to meet the requirements of SEPA and function as the appropriate level of documentation needed. The document will be prepared concurrently with the air permit application (for Ecology).

(Refer to Appendix $A$ for the Project $W$-259's air permitting schedule.)

\subsection{RESOURCE CONSERVATION AND RECOVERY ACT}

The RCRA (42 USC 6901 et seq.) was enacted as a comprehensive national program to mandate that hazardous waste be treated, stored, and disposed to minimize the present and future threat to human health and the environment. Washington State implements RCRA through WAC 173-303, Dangerous Waste Regulations. 


\subsection{INTRODUCTION}

The WAC 173-303 regulations apply to all facilities within Washington State that treat, store, and/or dispose of dangerous waste. These regulations are equivalent to, or more stringent than, the federal hazardous waste regulations. Under the dangerous waste program, a11 TSD facilities must obtain a permit. Facilities that were in existence on November 19, 1980, were granted an interim status permit with the submittal of a Part A, Form 3 , permit application identifying the intent to TSD of dangerous waste. Interim status ends after final administrative disposition of Part B permit

application documentation is completed, and a final status permit is granted or denied.

An application for a TSD facility permit consists of three collective submittals. Each submittal consists of various levels of detailed information concerning the facility. The three submittals are the notice of intent (NOI), the Part A permit application (Part A, Form 3), and the Part B permit application documentation (Part B).

\subsubsection{Notice of Intent}

A NOI is required for proposed facilities and expansion at an existing facility. Expansion includes enlargement of 1 and surface area, the addition of new dangerous waste process, or an increase in overall design capacity. The NOI contains preliminary information concerning the proposed facility and/or expansion (WAC 173-303-281). The NOI requires a general process description, operating capacities, waste type, a topographic map, a statement of environmental conditions, and could include a SEPA environmental checkl ist.

In accordance with WAC 173-303-281, the NOI must be submitted to the public (public reading rooms), Ecology, and the U.S. Environmental Protection Agency, Region 10. A public notification is published in a local daily newspaper for 14 consecutive days. The NOI process normally requires approximately 11 months to complete. A Part A, Form 3 , is submitted no earlier than 150 days following submittal of the NOI to Ecology and the public.

\subsubsection{Part A}

The Part A, Form 3, includes process design capacity, process description, dangerous waste numbers (WAC 173-303) and estimated annual quantity, description of dangerous waste, facility diagrams, photographs, geographic location, and facility owner, operator/co-operator certification.

\subsubsection{Part B}

The Part B permit application documentation provides a detailed definition of the processes to be used for treatment, storage, and/or disposal of dangerous waste; the design capacity of such processes; and the specific dangerous waste types to be managed. This detailed information is used by the 
regulatory agency(s) to prepare a final status permit for the operation of the TSD facility.

\subsection{SUMMARY OF DATA/INFORMATION REQUIREMENTS}

A summary of the minimum data and/or information needs required for development of permit application documentation is provided in Appendix B.

\subsection{DISCUSSION OF ALTERNATIVES}

Various avenues were evaluated in an effort to support the $T P 1$ ant Complex Secondary Containment Upgrades. The alternatives open for consideration follow and are listed in order of probability and success.

1. The Dangerous Waste Part B Permit application for the T Plant Complex (DOE/RL-96-36) was prepared and submitted per TPA Milestone M-20-51 (due date December, 1995). The subject Part B is scheduled to be incorporated into the Hanford Facility RCRA Permit in 2001. It is not expected that any additional changes from Project $W-259$ will be required.

2. The Part A will need to be modified after the upgrades are completed to discuss the up-to-date activities.

\subsection{RECOMMENDED PERMITTING STRATEGY}

Project W-259's upgrades were included in the Part B permit application documentation submitted in December 1995 to Ecology. The T Plant Complex Part B is scheduled to be incorporated into the Hanford Facility RCRA Permit in 2001, and no additional Project $W-259$ changes are expected to be required. However, the T Plant Complex Part A will need to be modified after the upgrades are completed to discuss the upgraded activities.

(Refer to Appendix A for the Project $W-259$ permitting schedule for the revision to the Part A.)

\subsection{THE CLEAN AIR ACT}

The Federal Clean Air Act (42 USC 7401 et seq.) was enacted in 1970, amended in 1977, and overhauled and expanded in 1990.

\subsection{INTRODUCTION}

The T Plant Complex Secondary Containment Upgrades, Project W-259, will require several permits and approvals before construction. These permits and approvals will be issued by several regulatory agencies, including the EPA, 
WHC-SD-W259-EV-001, Rev. 0

Ecology, Washington State Department of Health (WDOH), and the Benton County Clean Air Authority.

Permitting and emission standards administered by these agencies are contained in the following regulations:

- NESHAPs (40 CFR 61 Subpart H)

- Prevention of Significant Deterioration (PSD) standards (40 CFR 52.21 and WAC 173-400)

- Ambient Air Quality Standards for Radionuclides (WAC 173-480)

- Radiation Protection - Air Emissions (WAC 246-247)

- Controls for New Sources of Toxic Air Pollutants (TAPs) (WAC 173-460).

\subsubsection{Radioactive Emissions}

Radioactive air emissions currently are regulated by both the EPA, pursuant to 40 CFR 61 Subpart $H$, and the WDOH, pursuant to WAC 246-247. Both regulations require preconstruction approval from the respective agencies. Additionally, the WDOH requires extensive information on the technologies chosen to control radioactive air emissions, including an assessment of all known control technologies. This assessment, referred to as a best available radionuclide control technology (BARCT) assessment, evaluates the universe of available control technologies. For T Plant upgrades, the "Best" technology must be installed, as determined by the BARCT assessment. The EPA also requires the sampling and monitoring system to meet specific criteria. These criteria, including requirements on the placement and number of sample probes, are applicable if the estimated dose equivalent from the facility to the maximally exposed offsite individual is greater than $0.1 \mathrm{mrem}$ per year and when, hypothetically, no emissions control equipment is in place but operations are otherwise routine.

The WAC 246-247 regulations require varying degrees of information depending on the quantity of emissions. It is expected that the these upgrades will require the highest level of information for the WAC 246-247 application, and will require preconstruction approval under the NESHAPS regulations.

Before the BARCT assessment, extensive information on the processes and expected emissions from these processes must be developed. This information is required to perform an adequate BARCT assessment. Information normally not available until definitive design (particularly concerning sampling equipment and expected emissions) is crucial to the preparation of the permit applications. 


\subsubsection{Nonradioactive Emissions}

Nonradioactive air emissions of concern are expected to fall into one of two categories: criteria pollutants and TAPs.

Criteria pollutants are those subject to the PSD program, enforced by Ecology. Ecology has incorporated by reference most of the federal PSD requirements. The $\mathrm{T} \mathrm{Plant}$ upgrades are not expected to allow emissions exceeding the trigger levels for criteria pollutants (this assumption is based on previous T Plant estimates).

The TAPs are a separate class of emissions, regulated by Ecology pursuant to WAC 173-460. Over 500 carcinogenic and toxic pollutants are included in these regulations. Emissions will occur during installation and operation of the ventilation systems associated with the T Plant upgrades; WAC 173-460 is applicable, and there is no de minimis level below which preconstruction approval is not required. While WAC 246-247 regulations require installation of BARCT, the TAPs regulations require the installation of best available control technology for toxics (T-BACT). Additionally, if emissions of pollutants (after controls) exceed the small quantity emission (SQE) rates included in the regulations, modeling must be performed to demonstrate that the offsite concentration of each pollutant of concern does not exceed the acceptable source impact levels. Some pollutants do not have SQE rates, and modeling is required for any level of emission.

If any criteria pollutant approaches its trigger level, the information required by the PSD process would be included in a single application to Ecology. Ecology refers to these air permit applications as Notices of Construction (NOCS).

\subsection{SUMMARY OF DATA/INFORMATION REQUIREMENTS}

A summary of the minimum data and/or information needs required for development of each of the air permit applications is provided in Appendix $B$.

\subsection{DISCUSSION OF ALTERNATIVES}

Various avenues may be evaluated in an effort to support the air permitting for the $\mathrm{T}$ Plant upgrades. The length of the permitting process depends on the quantity of emissions and the availability of necessary information. The following alternatives are being considered and are listed in order of general preference.

1. Secure WAC 246-247 approval for Project W-259 activities (in a regulatory streamlined manner) by obtaining WDOH signature after a presentation at a routine meeting. Submit the approval from WDOH to the EPA for 40 CFR 61 Subpart $H$ (NESHAPs). Obtain the emissions estimate data that will demonstrate that emissions are below the smal1 quantity emission rates (SQERs) for WAC 173-460 (TAPs) and that the permit application will not be required. 
WHC-SD-W259-EV-001, Rev. 0

2. Apply for and secure WAC 173-460 (TAPs), WAC 246-247, and 40 CFR 61 Subpart $H$ (NESHAPs) approvals for a 11 of Project $W-259$ before construction by submitting full permit applications to the agencies.

\subsection{RECOMMENDED PERMITTING STRATEGY}

The recommended strategy for Project $W-259$ is to secure the air permits before construction in a regulatory streamlined manner. The present strategy is to obtain WDOH approval in a routine meeting, with a copy of that acceptance submitted to EPA for approval (in required format). However, WDOH may require a ful1 NOC application for WAC 246-247 approval activating a NESHAPs submitta] (40 CFR 61 Subpart $H$ ) to the EPA. However, if emissions estimates substantiate (per the representative samples presently being collected) that TAPS emissions will be under the SQERs, a TAPs application will not be required per WAC 173-460 (because Project $W-259$ is considered a minor modification). Project $W-259$ is not expected to exceed significance levels for any criteria pollutants under the PSD program.

The 2706-TA Building will have an independent ventilation system installed (similar to the existing system), and will be ducted to the existing 296-T-7 stack. This stack is equipped with a NESHAPs-compliant monitoring system that samples the air leaving the building and measures total stack air flow.

Installation of BARCT will be required by WAC 246-247 and T-BACT may be required by the TAPs program.

(Refer to Appendix A for the Project W-259 permitting schedule.)

\subsection{Miscellaneous assessments, PERMits, AND APPROVALS}

In addition to the major regulatory programs, several miscellaneous assessments, permits, and approvals are addressed in the following sections.

\subsection{CULTURAL RESOURCE REVIEW}

A cultural resource review (CRR) is needed before initiating any potential onsite surface disturbing activities (36 CFR 800 ). The regulatory agency is the DOE-RL. A review was completed for Project $W-259$ in December 1993, that encompassed the project activities.

In addition, a historical review was conducted for the 2706-T/TA building. The review indicated that Project $W-259$ modifications will have no adverse effects on the 2706-T/TA building and that the building does not meet any of the criteria of the National Historic Preservation Act. However, if any archaeological or historical resources are discovered during project activities, work is required to be halted. 


\subsection{EXCAVATION PERMIT}

An excavation permit will be required before initiating any potential onsite surface disturbing activities (36 CFR 800 ). The regulatory agency is the DOE-RL. The excavation permit, prepared before upgrades and construction activities will evaluate environmental impacts (e.g., soil and/or groundwater contamination).

\subsection{ENDANGERED SPECIES ACT COMPLIANCE}

A site assessment should be made to determine whether any planned activities have the potential to disturb any habitat used by wildlife before construction or habitat modification (50 CFR 402.6). The regulatory agency is the State or Federal Fish and Wildlife Service. For onsite construction, a biological survey will be is performed.

\subsection{PREOPERATIONAL MONITORING OF FACILITIES, SITES, AND OPERATIONS}

An environmental study must be conducted before start up of a new site, facility, or process that has the potential for significant adverse environmental impact (DOE order 5400.1). The reguilatory agency is the DOE-RL.

As part of the preoperational monitoring requirements, a document needed for construction will be prepared that will specify the types of monitoring to be performed (e.g., radiation dose, ambient air, and surface radiological surveys).

\subsection{REFERENCES}

DOE-RL, 1994, National Environmental Policy Act Categorical Exclusion Determination: Project $W-259$, $T$ Plant Secondary Containment and Leak Detection Upgrades at $T$ Plant, 200 West Area, Hanford Site, Richland, Washington, U.S. Department of Energy, Richland Operations Office, Waste Management Division.

D0E/RL-95-36, Hanford Facility Dangerous Waste Permit Application, T Plant Complex, U.S. Department of Energy, Richland Operations Office, Richland, Washington.

Ecology, 1995, Dangerous Waste Permit Application Requirements; 95-402, Washington State Department of Ecology, 0lympia, Washington.

EPA, 1996, "A Computerized Methodology for Estimating Environmental Concentrations and Dose to Man from Airborne Releases of Radionuclides", AIRDOS-EPA, EPA-5201-79-009, updated periodically, U.S. Environmental Protection Agency, Washington, D.C.

WHC, 1993, Ecological Survey of T Plant, Internal Memo \#25320-93-032, Westinghouse Hanford Company, Richland, Washington. 
WHC-SD-W259-EV-001, Rev, 0

WHC, 1995, Categorically Excluded Determination: Project W-259, T-Plant Secondary Containment and Leak Detection Upgrades at T-Plant, 200 West Area, Hanford Site, Richland, Washington, Internal Memo \#01880-95-072, Westinghouse Hanford Company, Richland, Washington.

WHC, 1995b, Engineering Evaluation Report for Project W-259, T Plant Secondary Containment and Leak Detection Upgrades, WHC-SD-W259-ER-001, Rev. 0 , Westinghouse Hanford Company, Richland, Washington. 
WHC-SD-W259-EV-001, Rev. 0

This page intentionally left blank. 
WHC-SD-W259-EV-001, Rev. 0

\section{APPENDICES}

A PROJECT $W-259$, T PLANT COMPLEX SECONDARY CONTAINMENT UPGRADES PERMITTING SCHEDULES

B SUMMARY OF DATA/INFORMATION REQUIREMENTS FOR PROJECT W-259, T PLANT COMPLEX SECONDARY CONTAINMENT UPGRADES 
WHC-SD-W259-EV-001, Rev. 0

This page intentionally left blank. 
WHC-SD-W259-EV-001, Rev. 0

\section{APPENDIX A}

PROJECT W-259, T PLANT COMPLEX SECONDARY CONTAINMENT UPGRADES PERMITTING SCHEDULES 
WHC-SD-W259-EV-001, Rev. 0

This page intentionally left blank.

APP $A-i i$ 


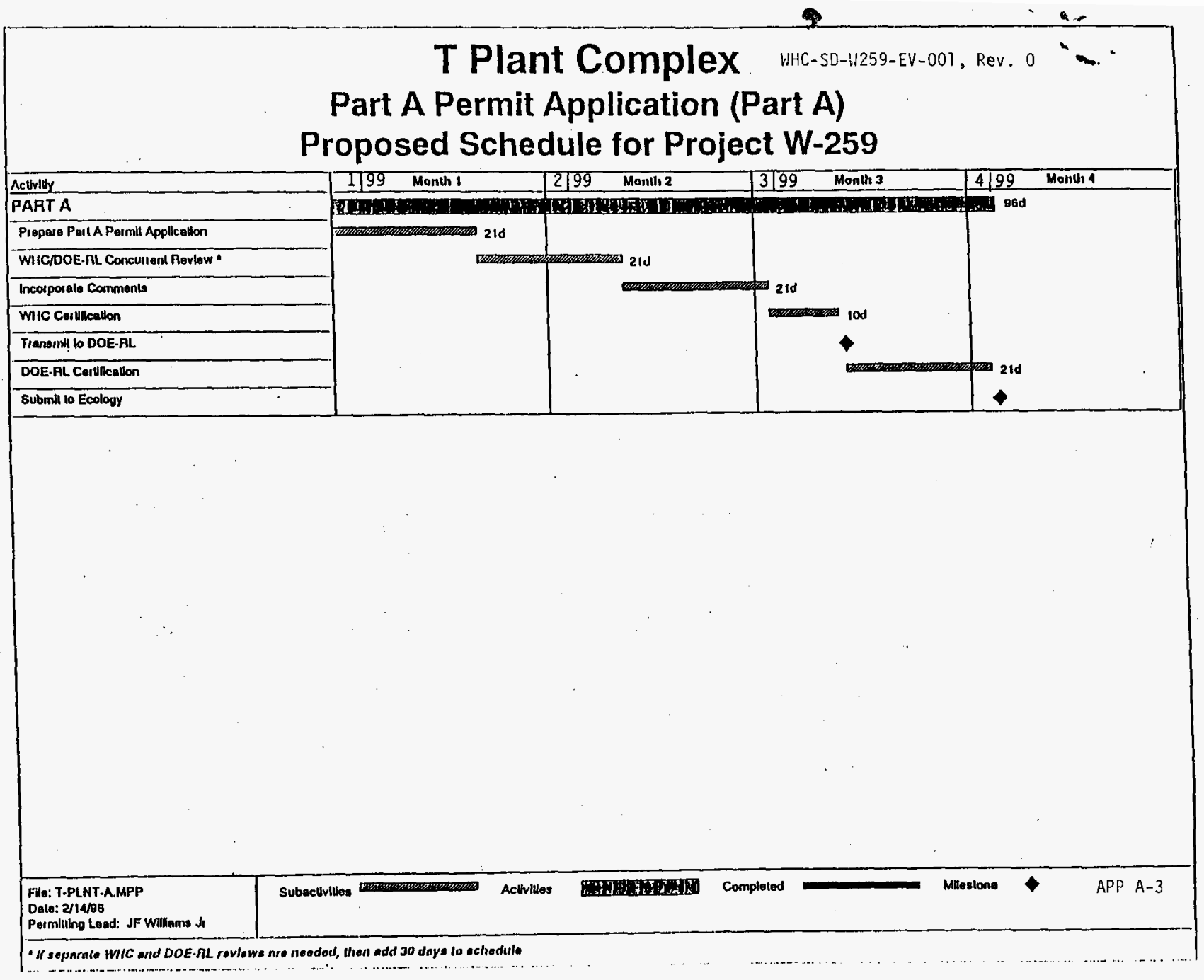


WHC-SD-W259-EV-001, Rev. 0

\section{APPENDIX B}

SUMMARY OF DATA/INFORMATION REQUIREMENTS FOR PROJECT W-259, $T$ PLANT COMPLEX SECONDARY CONTAINMENT UPGRADES 
WHC-SD-W259-EV-001, Rev. 0

This page intentionally left blank.

APP $B-i i$ 
WHC-SD-W259-EV-001, Rev. 0

\section{SUMMARY OF DATA/INFORMATION REQUIREMENTS FOR PROJECT W-259, $T$ PLANT COMPLEX SECONDARY CONTAINMENT UPGRADES}

\subsection{NATIONAL ENVIRONMENTAL POLICY ACT}

The minimum data and/or information requirements for NEPA documentation preparation are as follows:

- Conceptual or equivalent design information

- In addition, any other related engineering, safety, or waste evaluation documents would be helpful in NEPA preparation.

\subsection{STATE ENVIRONMENTAL POLICY ACT}

The following are minimum data requirements for coordination of the SEPA requirements (SEPA environmental checklist to Ecology). The TAPS air permit and/or approval may be conditioned or denied based on information contained in the SEPA environmental checklist.

- Conceptual or equivalent design information is needed

- Any NEPA documentation (e.g., EA) that has been prepared or will be prepared for Project $W-259$.

- Any other related engineering, safety, or waste evaluation documents.

\subsection{RESOURCE CONSERVATION AND RECOVERY ACT}

The following is required for the revised Part A documentation: description of activities associated with upgrades and design media.

\subsection{CLEAN AIR ACT}

Detailed information on the treatment process, the emissions abatement system, the gaseous effluent monitoring system, and the nature of all gaseous emissions to the atmosphere is required for submissions made pursuant to the Clean Air Act. The appropriate regulations and administrative guidance should be consulted for the detailed requirements.

\subsection{Radioactive Emissions}

The following information is an abridged summary of the data and/or information needs for the NESHAP and WAC 246-247 permit applications and notice of construction. 
WHC-SD-W259-EV-001, Rev. 0

\section{NESHAP Permit}

The 40 CFR 61.07 requires the application for approval to construct to include the following information:

- Technical description of the facility and its operations

- Size and location of the source

- Design and operating capacity of the source

- Method of operation (include process flow diagram)

- Nature of al1 gaseous emissions to the atmosphere:

- If a modification, the precise nature of the modification and estimates of emissions before and after completion.

- Technical description of emissions control system including release rates and offsite doses.

\section{WAC 246-247 Permit}

The WAC 246-247 regulations requires the application for approval to construct to include the following information:

- Facility information:

- Description of facility operations

- Facility identification must be the same as that appearing on source registration forms.

- Identification and listing of all sources consistent with the source registration identification

- Description of the source(s):

- System function and area exhausted

- Effluent system layout

- Efficiency values of each control device for removal of radioactivity

- Means and frequency of testing and inspecting effluent treatment system

- Operating mode (continuous or batch)

- Chemical and physical nature of the emissions

- Stack or release point data 
- Stack diameter and height

- Building height, width, and length

- Annual ambient average stack and ambient air temperatures

- Annual wind rose

- Chi/Q data

- Annual average volumetric flow rate

- Annual average release rates

- Fraction of facility's inventory available for potential release to the air.

- Description of the effluent sampling/monitoring systems:

- Stack flow measuring system

- Sample probes (isokinetic)

- Number and location of sampling points

- Sample lines

- Diameters, lengths, materials, bends, entry points into the effluent line, and angle of entry into the effluent

- Sample flow regulation

- Sampling media

- Frequency of sampling (continuous or batch)

- Frequency of sample collection

- Calibration and audit schedules.

- Environmental sampling monitoring system:

- Sampling network (location, number, distance from release points)

- Media sampled and/or monitored for the air pathway

- Equipment used for sampling and/or monitoring, including sampler flow rate and collection media

- Frequency of sampling and/or monitoring

- Calibration and audit frequency. 
- Hanford Site requirements for effluent sampling and/or monitoring system designs, procedures, and quality assurance standards (appropriate standards and description of how these are used)

- Effluent sample analyses including methodology, procedure references, detection limits, quality assurance (including internal audit schedule and results)

- Environmental sample analysis including methodology, procedure references, detection limits, quality assurance

- Data from effluent and environmental monitoring programs, including background or local control data

- Demonstration of compliance:

- Methodology used to demonstrate compliance

- Input data used

- Source terms, release height, inhalation rate, maximally exposed individual, meteorology

- Results of method (effective dose equivalent for whole body and relevant organs)

- Description of internal standards used to ensure compliance with applicable federal and state laws and regulations.

\subsection{Nonradioactive Air Emissions}

The following information is an abridged summary of the data and/or information needs for the NESHAP and WAC 246-247 permit applications and notice of construction.

\section{PSD Permit}

The WAC 173-400 regulations require an application for approval to construct to include such information as the following:

- Project location and emission source(s)

- Design and operating parameters:

- Hours of operation

- Normal and maximum production rates

- Fuel requirements 
- Raw material requirements

- Emissions control system.

- Emissions - Type and Quantity:

- Representative emissions from the existing source (for modification) over the most recent 2 year period of operation

- Projected actual controlled emissions at anticipated production rates and operating schedule for each pollutant at each emission point

- Projected potential controlled emissions; emission rate when equipment is operating at maximum capacity 24 hours per day, 365 days per year, taking air pollution control equipment into account.

- BACT/BARCT assessment:

- Literature search

- Control alternatives: comparison of efficiencies; energy, environmental, and economic impact analyses

- Summary.

- Analysis of current air quality at the proposed source location including presently existing ambient levels of the constituents being reviewed (from Pacific Northwest National Laboratory data)

- Analysis of the impact of the proposed source on ambient air quality:

- Model description

- AIRDOS - EPA 1996

- Meteorological data (windspeed, direction, temperature)

- Modeling results

- Offsite dose.

- Demonstration that the proposed emission will not cause a violation of national ambient air quality standards (NAAQS) or state standards using a direct comparison of modeling results with NAAQS

- Discussion of potential effects of the proposed upgrades on factors influenced by air quality such as residential or commercial growth, vehicular traffic, vegetation, soils, acid deposition, visibility in sensitive areas, PSD increments, etc.

- Construction schedule. 
WHC-SD-W259-EV-001, Rev. 0

\section{Notice of Construction}

The WAC 173-400 and 173-460 regulations require the application for approval to construct to include the following information:

- SEPA

- Notice of construction form

- Description of proposed source:

- Bid specifications, rated capacity, inputs, outputs, and byproducts generated

- Bid specifications, control efficiency, and operational requirements of the pollution control equipment

- Process flow diagram

- Estimate of stack emissions, including criteria and toxic air polTutants.

- Estimate of fugitive (nonstack) emissions

- BACT/T-BACT analysis

- Madeling. 


\section{DISTRIBUTION SHEET}

\begin{tabular}{|c|c|c|}
\hline \multirow{2}{*}{$\begin{array}{l}\text { To } \\
\text { Distribution }\end{array}$} & \multirow{2}{*}{$\begin{array}{l}\text { From } \\
\text { R. J. Swan }\end{array}$} & Page 1 of 1 \\
\hline & & Date June 28, 1996 \\
\hline \multicolumn{2}{|c|}{ Project Title/Work Order } & EDT No. 615843 \\
\hline \multicolumn{2}{|c|}{$\begin{array}{l}\text { Permitting Plan for Project } W-259, T \text { Plant Complex Secndary } \\
\text { Containment Upgrades }\end{array}$} & ECN No. N/A \\
\hline
\end{tabular}

\begin{tabular}{c|c|c|c|c|c}
\hline Name & MSIN & $\begin{array}{c}\text { Text } \\
\text { With All } \\
\text { Attach. }\end{array}$ & $\begin{array}{c}\text { Text } \\
\text { Only }\end{array}$ & $\begin{array}{c}\text { Attach./ } \\
\text { Appendix } \\
\text { Only }\end{array}$ & $\begin{array}{c}\text { EDT/ECN } \\
\text { Only }\end{array}$ \\
\hline
\end{tabular}

A. A. Carlson

G. D. Cummins

W. T. Davis

L. P. Diediker

B. J. Dixon

R. H. Engelmann

D. P. Fassett

T. P. Frazier

C. K. Girres

J. I. Gould

E. M. Greager

J. J. Luke

K. J. Moss

S. M. Price

J. W. Schmidt

R. J. Swan

W. E. Toebe

J. F. Williams, Jr.

Central Files
T3-28

H6-26

H6-20

S3-95

B4-20

H6-26

T3-28

H6-25

T3-28

H6-22

H6-20

H6-25

S3-24

H6-23

H6-20

H6-21

H6-22

H6-24

A3-88 $x$

$x$

$x$

$x$

$x$

$x$

$x$

$x$

$x$

$x$

$x$

$x$

$x$

$x$

$x$

$x$

$x$

$x$

$x$ 